\title{
Evaluasi Kebijakan Sosialisasi Penerimaan Mahasiswa Baru Pascasarjana IAIN Kendari
}

\author{
Akib \\ Fakultas Tarbiyah dan Ilmu Keguruan IAIN Kendari \\ Email: qomarabu9@gmail.com
}

\begin{abstract}
Abstrak
The purpose of this research is to study how this program can be implemented. the extent to which the program is implemented, the achievement of program objectives as determined, and to look for relationships in the implementation of the program. The research method used is qualitative research. The evaluation research model used is the DEM (Discrepancy Evaluation Model), a model according to Provus which is also called the Gap Model. This is based on the implementation of the socialization of new student admissions in Islamic economics courses. It is necessary to see the agreement made between the expected results and those that occur in the field as a benchmark to improve the implementation of recruitment. The evaluation results show that the implementation of the socialization policy for admission of new students for the IAIN Kendari postgraduate program has been carried out in accordance with the academic guidelines of the IAIN Kendari and the provisions of the postgraduate IAIN Kendari RKAKL. include: Definition Stage, Installation Stage, Process Stage, Product Stage, Product Comparison Stage Some things that become recommendations to the stakeholders are: 1) Need to develop forms of cooperation with related institutions, especially those related to study permits for civil servants who are in the scope of the Ministry of Religion of Southeast Sulawesi Province, local governments and the business world. 2) Increase the number and competence of lecturers and postgraduate management staff so that they can disseminate effectively to related institutions. 3) Need to prepare sufficient funds to carry out promotions and outreach through print, electronic media, visits to offices and schools and through online information media. 4) Encourage various efforts to conduct socialization by accelerating the issuance of assignments including disbursement of socialization funds prior to implementation of the socialization
\end{abstract}

Keywords: Socialization Policy, Discrepancy Evaluation Model 


\section{Pendahuluan}

Penyelenggaraan pascasarjana IAIN Kendari dilaksanakan sejak memperoleh izin penyelenggaraan dari Direktur Jenderal Pendidikan Islam Kementerian Agama RI. Nomor 1850 tahun 2013 tentang Izin Penyelenggaraan Pascasarjana IAIN Kendari program studi Manajemen Pendidikan Islam.

Sejak diterbitkannya SK Ijin Penyelenggaraan Program Studi Manajemen Pendidikan Islam, penegmbangan dan penambahan program studi dilakukan dengan mengusulkan tiga (3) program studi yakni; Pendidikan Agama Islam, Ekonomi Syariah dan Hukum Islam. Enam bulan kemudian SK Dirjen No. 544, tanggal 28 Januari 2015 tentang Ijin Program Studi Pendidikan Agama Islam, SK Dirjen Pendidikan Islam Nomor : 1111 Tahun 2015 ijin program studi Hukum Islam dan Ekonomi Syari'ah. Sehingga saat ini jumlah program studi di Pascasarjana sebanyak 4 program studi.

Berdasarkan dokumen data perkembangan jumlah mahasiswa yang sudah memasuki tahun ke-5 relatif masih sedikit terutama program studi Ekonomi Syari'ah dan Hukum Islam ${ }^{1}$. Hal ini menjadi penting untuk melakukan penelusuran secara mendalam melalui evaluasi kebijakan sosialisasi penerimaan mahasiswa baru pada Pascasarjana IAIN Kendari.

Evaluasi Kebijakan sosialisasi dimaksudkan untuk mengetahui; apakah sosialisasi penerimaan mahasiswa baru telah dilaksanakan sesuai dengan pedoman yang telah ditetapkan pada pedoman akademik IAIN Kendari, hambatan dan masalah yang menjadi penyebab kurangnya animo masyarakat melanjutkan studi pada Pascasarjana IAIN Kendar.

Berdasarkan fakta diatas terlihat adanya ketidak sesuaian dengan harapan dari pengelola terhadap jumlah pendaftar calon mahasiswa baru. Atas dasar inilah perlunya dilakukan penelitian untuk menganalisis faktor-faktor penyebab kurangnya animo masyarakat untuk lanjut studi magister pada pascasarjana IAIN Kendari.

\section{Kerangka Teori}

\section{Kebijakan dan Evaluasi Kebijakan}

1 Data Hasil penelusuran data pendaftar Mahasiswa Baru Pascasarjana IAIN Tahun 2014-2019. 
Menurut Weihrich dan Koontz bahwa kebijakan adalah alat membersihkan hati atau harapan yang mendorong, inisiatif tetapi dalam keterbatasan. Kebebasan tergantung pada kebijakan dan sebaliknya akan merefleksikan posisi dan kekuasaan dalam organisasi ${ }^{2}$. Kebijakan juga adalah rencana, kebijakan itu sebagai pernyataan atau pemahaman atau pengertian yang mengarahkan pikiran dalam membuat keputusan. Tidak semua kebijakan merupakan pernyataan, tetapi sering hanya diimplikasikan dari tindakan manajer ${ }^{3}$. Membuat kebijakan itu tetap (konsisten) dan terintegrasi dalam tujuan perusahaan adalah berbeda dalam banyak hal alasannya (1) kebijakan jarang didefinisikan dalam tulisan dan interprestasinya sedikit, (2) penguasa yang kebijakanya ditujukan untuk mengarahkan, disentralisasi pengaruh, memperluas partisipasi dalam pengambilan keputusan dan interprestasi dengan berbagai variasi diantara individu, (3) tidak selalu mudah untuk mengawas kebijaksanaan, karena kebijakan sebenarnya mungkin sukar untuk dilaksanakan dan tidak selalu jelas. ${ }^{4}$ Mullins mengatakan bahwa kebijakan adalah outline sikap atau aksi organisasi dan implementasi tujuan dan hasil, juga diartikan sebagai peraturan, rencana, dan prosedur, berhubungan dengan semua aktivitas organisasi dan terhadap semua tingkatan organisasi' Sedangkan kebijakan organisasi adalah garis besar tindakan dan keputusan, kebijakan adalah keputusan yang diambil lebih dahulu untuk menggambarkan situasi, mengatur keterbatasan, untuk membuat keputusan atau bertindak. Kebijakan menyediakan anggota organisasi kerangka kerja untuk mengambil keputusan supaya tindakan tersebut konsisten dalam keseluruhan sistem. ${ }^{5}$

Lebih lanjut Muhadjir mengatakan bahwa kebijakan dapat dibedakan menjadi dua yaitu kebijakan subtantif dan kebijakan implementatif. Kebijakan subtantif adalah keputusan yang dapat diambil berupa memilih alternatif yang dianggap benar untuk mengatasi masalah. Tindak lanjut dari kebijakan subtantif adalah kebijakan implementatif

\footnotetext{
${ }^{2}$ Heinz Weihrich and Harold Koontz, Management A Global Perspective Tent Edition (New York: McGraw-Hill, Inc, 1993), h.123.

${ }^{3}$ Ibid.,h.125.

${ }^{4}$ Ibid.,h. 125

5 Charles E. Merrill, Business Policy and Strategic Management, (USA: Bell \& Howrill Company, 1990). h.8.
} 
yaitu keputusan-keputusan yang berupa upaya-upaya yang harus dilakukan untuk melaksanakan kebijakan subtantif. ${ }^{6}$

Dengan demikian berdasarkan beberapa pendapat tersebut di atas, dapat disimpulkan bahwa kebijakan adalah sebagai rangkaian konsep dan azas yang menjadi garis besar dari dasar rencana dalam pelaksanaan suatu pekerjaan, kepemimpinan dan cara bertindak, pernyataan cita-cita, tujuan, prinsip, atau maksud sebagai garis pedoman untuk manajemen dalam usaha mencapai sasaran, garis haluan. Dengan kata lain sebagai pedoman untuk bertindak, pembatas perilaku dan bantuan bagi pengambilan keputusan.

Pengertian evaluasi menurut Sudijono mengemukan bahwa secara harfiah kata evaluasi berasal dari bahasa Inggris Evaluation, dalam bahasa Indonesia berarti penilaian. Jadi istilah evaluasi menunjuk pada suatu tindakan atau suatu proses untuk menentukan nilai dari sesuatu ${ }^{7}$.

Pengertian para pakar evaluasi memformulasikan definisi mengenai evaluasi dengan formulasi yang berbeda, akan tetapi inti isinya sama yaitu mendefenisikan riset evaluasi atau evaluasi sebagai riset untuk mengumpulkan, menganalisa, dan menyajikan informasi yang bermanfaat mengenai objek evaluasi, menilai dengan membandingkannya terhadap indikator evaluasi dan hasilnya dipergunakan sebagai bahan pertimbangan bagi pengambil keputusan dalam menentukan alternatif kebijakan.

Fitzpatrik, J. L James R. Sanders, Elaini R Worthen, bahwa penelitian evaluasi mengandung makna pengumpulan informasi tentang hasil yang telah dicapai oleh sebuah program yang dilaksanakan secara sistematis dengan menggunakan metodologi ilmiah sehingga darinya dapat dihasilkan data yang akurat dan objektif. ${ }^{8}$

Evaluasi kebijakan menurut Carol dilakukan untuk mengetahui: 1) proses pembuatan kebijakan; 2) proses implementasi; 3) konsekuensi kebijakan; 4) efektivitas dampak kebijakan ${ }^{9}$..

\footnotetext{
${ }^{6}$ Noeng H. Muhajir, Metodologi Penelitian Kebijakan dan Evaluation Research, (Yogyakarta: Rake Sarakin, 2003). h.90.

${ }^{7}$ Anas Sudijono, Pengantar Evaluasi Pendidikan (Jakarta: Raja Grafindo Persada., 2011),p. 7

${ }^{8}$ Worten B. Blaini. Sanders, R. James, Fitzpatrick, L. Jodi , op.cit.,h.3

9 Carol H. Weiss, Evaluation Research : Methods for Assessing Program Effectiveness, (New Jersey: Prentice Hall, 1972).h. 172.
} 
Dari pengertian tersebut maka evaluasi merupakan kegiatan mencari dan menyajikan informasi guna menetapkan suatu keputusan atau penilaian suatu kegiatan. Keputusan tersebut berkisar diantara hal berikut: apakah program tersebut dapat dilanjutkan atau tidak. jika dilanjutkan apakah ada penambahan atau pengurangan materi dan metode serta sarana pendukung lainnya atau tidak. atau program tersebut tidak layak lagi untuk diteruskan karena kurang bermanfaat Browne \& Wildavsky menyatakan bahwa "Evaluators are able to tell us a lot about what happened - which objectives, whose objectives, were achieved - and a little about why - the causal connections" ${ }^{10}$.

\section{Implementasi Kebijakan}

Implementasi kebijakan adalah studi perubahan yang terjadi dan perubahan bisa dimunculkan, juga merupakan studi tentang mikrostruktur dari kehidupan politik yaitu organisasi di luar dan di dalam sistem politik menjalankan urusan mereka dan berinteraksi satu sama lain dan motivasi yang membuat bertindak secara berbeda Parsons. ${ }^{11}$

Dalam setiap perumusan suatu tindakan apakah itu menyangkut program maupun kegiatan-kegiatan selalu diiringi dengan suatu tindakan pelaksanaan atau implementasi, karena suatu kebijaksanaan tanpa diimplementasikan maka tidak akan banyak berarti. Sesuai dengan hal tersebut, Van Meter dan Van Horn (dalam Winarno) mengemukakan "Implementasi kebijakan sebagai tindakan-tindakan yang dilakukan oleh individu-individu (kelompok-kelompok) pemerintah maupun swasta yang diarahkan untuk mencapai tujuantujuan yang telah ditetapkan dalam keputusan-keputusan kebijakan sebelumnya". ${ }^{2}$

Standar dan sasaran kebijakan didasarkan pada kepentingan utama terhadap faktor-faktor yang menentukan pencapaian kebijakan. Mengiden-tifikasi indikator-indikator pencapaian merupakan tahap yang krusial dalam analisis implementasi kebijakan. Indikatorindikator pencapaian ini menilai sejauh mana ukuran-ukuran dasar dan

\footnotetext{
${ }^{10}$ Michael Hill \& Peter Hupe, Implementing Public Policy: Governance in Theory and Practice, (London: Sage Publication, 2002).h.12

${ }^{11}$ Op.Cit. Wayne Parsons, h. 463

12 Budi Winarno, Teori dan Proses Kebijakan Publik. (Jakarta : Erlangga, 2002). h.57.
} 
tujuan-tujuan kebijakan telah direalisasikan. Dampak kondisi-kondisi ekonomi, sosial dan politik pada kebijakan publik merupakan pusat perhatian yang besar selama dasawarsa yang lalu. Para peminat perbandingan politik dan kebijakan publik secara khusus tertarik dalam mengidentifikasikan pengaruh variabel-variabel lingkungan pada hasil-hasil kebijakan. Faktor-faktor implementasi keputusankeputusan kebijakan mendapat perhatian yang kecil, namun menurut Van Meter dan Van Horn, faktor-faktor ini mempunyai efek yang mendalam terhadap pencapaian badan-badan pelaksana.

Sedangkan menurut George C. Edwards "Implementasi kebijakan adalah salah satu tahap kebijakan publik, antara pembentukan kebijakan dan konsekuensi-konsekuensi kebijakan bagi masyarakat yang dipengaruhinya". ${ }^{13}$ Jika suatu kebijakan tidak tepat atau tidak dapat mengurangi masalah yang merupakan sasaran dari kebijakan, maka kebijakan itu dapat mengalami kegagalan sekalipun kebijakan itu diimplementasikan dengan sangat baik. Sementara itu, suatu kebijakan yang telah direncanakan dengan sangat baik, dapat mengalami kegagalan jika kebijakan tersebut kurang diimplementasikan dengan baik oleh para pelaksana kebijakan.

Selanjutnya dikemukakan oleh Charles O'Jones (dalam Harahap) mengemukakan 'Implementasi adalah suatu proses interaktif antara suatu perangkat tujuan dengan tindakan atau bersifat interaktif dengan kegiatan-kegiatan kebijaksanaan yang mendahuluinya, dengan kata lain implementasi merupakan kegiatan yang dimaksudkan untuk mengoperasikan sebuah program dengan pilar-pilar organisasi, interpretasi dan pelaksanaan". ${ }^{14}$

Sedangkan menurut Mazmanian dan Sabatier (dalam Gustina), menjelaskan lebih lanjut tentang konsep implementasi kebijakan sebagai berikut: Memahami apa yang senyatanya terjadi sesudah program dinyatakan berlaku atau dirumuskan merupakan fokus perhatian implementasi kebijakan, yaitu kejadian-kejadian atau kegiatan yang timbul setelah disahkannya pedoman- pedoman kebijakan negara, yaitu mencakup baik usaha-usaha untuk

\footnotetext{
13 George C. Edwards, Implementasi Kebijakan Publik, (Yogyakarta: Lukman Offset, 2003). h.1

14 J.S. Harahap, Implementasi Proyek Jalan dan Jembatan, Tesis-S2. (Medan: Program Pascasarjana Universitas Sumatera Utara, 2004). h.40.
} 
mengadministrasikannya maupun untuk menimbulkan akibat/dampak nyata pada masyarakat atau kejadian-kejadian. ${ }^{15}$

Drucker (dalam Eriza) merumuskan "Implementasi merupakan tindakan tindakan yang dilakukan dalam rangka pencapaian tujuan yang telah digariskan terlebih dahulu" ${ }^{\prime 6}$. Sedangkan Tangkilisan berpendapat "Implementasi kebijakan adalah untuk menetapkan arah agar tujuan kebujakan publik dapat direalisasikan sebagai hasil dari kegiatan pemerintah". ${ }^{17}$

Implementasi kebijakan merupakan tahap yang krusial dalam proses kebijakan publik. Suatu program kebijakan harus diimplementasikan agar mempunyai dampak atau tujuan yang diinginkan. Dunn. W. D. menganjurkan bahwa di setiap tahapan proses kebijakan publik, termasuk tahapan implementasi kebijakan, penting dilakukan analisa ${ }^{18}$. Analisa di sini tidak identik dengan evaluasi, karena dari tahapan penyusunan agenda hingga Policy Evaluation sudah harus dilakukan analisa. Ungkapan Dunn yang terkenal adalah lebih baik perumusan masalah public benar tapi pelaksanaan salah, daripada perumusan masalah keliru tapi pelaksanaannya benar. Hal ini memberi arti penting kesinambungan tahapan kebijakan, termasuk implementasi yang tepat bagi pengujian kendaraan bermotor untuk kepentingan publik yang memang suatu kebutuhan masyarakat, sehingga persoalan-persoalan publik mendapat solusi yang tepat melalui implementasi.

\section{Model Evaluasi Yang Digunakan}

Penelitian ini menggunakan Evaluasi Model Discrepancy Evaluation (DEM). DEM dikenal dengan evaluasi kesenjangan program. Kesenjangan program adalah sebagai suatu keadaan antara

\footnotetext{
${ }^{15}$ Ida Gustina, Implementasi Program Penanggulangan Kemiskinan di Perkotaan (P2KP) di Kecamatan Medan Maimun, Tesis-S2. (Medan: Program Pascasarjana Universitas Sumatera Utara, 2008). h. 65.

16 Eriza, F. Implementasi Proyek Pengelolaan Sumber Daya Pesisir dan Laut/Marine

Coastal Resources Management Project (Studi Deskriptif di Kabupaten Langkat), Tesis-S2. (Medan: Program Pascasarjana Universitas Sumatera Utara, 2006). h. 72.

17 Tangkilisan, H.N.S. Kebijakan Publik Yang Membumi, (Yogyakarta: Lukman Offset.2003). h. 26.

18 Dunn, N. William, Analisis Kebijakan Publik. (Yogyakarta : Gajah Mada University Press, 2003). h. 237.
} 
yang diharapkan dalam rencana dengan yang dihasilkan dalam pelaksanaan program. Evaluasi kesenjangan dimaksudkan untuk mengetahui tingkat kesesuaian antara standard yang sudah ditentukan dalam program dengan penampilan aktual dari program tersebut. Standar adalah: kriteria yang telah dikembangkan dan ditetapkan dengan hasil yang efektif. Penampilan adalah: sumber, prosedur, manajemen dan hasil nyata yang tampak ketika program dilaksanakan. Dengan model ini, proses evaluasi sesuai dengan langkah-langkah pengembangan menurut Provus adalah ${ }^{19}$,

1. Dalam definition stage (tahap definisi), mengorganisir a) gambaran tujuan, proses, atau aktivitas dan kemudian b) menggambarkan sumber daya yang diperlukankan. Harapan atau standar ini adalah dasar dimana evaluasi berkelanjutan.

2. Dalam installation stage (langkah instalasi), desain/ definisi program menjadi standar baku untuk diperbandingkan dengan penilaian operasi awal program. Gagasannya adalah untuk menentukan sama dan sebangun, sudah atau tidaknya program telah diterapkan sebagaimana desainnya.

3. Dalam process stage (tahap proses), evaluasi ditandai dengan pengumpulan data untuk menjaga keterlaksanaan program. Gagasannya adalah untuk memperhatikan kemajuan kemudian menentukan dampak awal, pengaruh, atau efek.

4. Dalam product stage (tahap produk), pengumpulan data dan analisa yang membantu ke arah penentuan tingkat capaian sasaran dari outcome. Dalam tahap 4 ini pertanyaannya adalah "Apakah sasaran program telah dicapai?" Harapannya adalah untuk merencanakan follow up jangka panjang pemahaman atas dampak.

5. Dalam optional tahap programe comparison, tahap membandingkan hasil yang telah dicapai dengan tujuan yang telah ditetapkan. Dalam tahap ini evaluator menuliskan semua penemuan kesenjangan untuk disajikan kepada para pengambil keputusan, agar mereka (ia) dapat memutuskan kelanjutan dari program tersebut.

\footnotetext{
${ }^{19}$ Provus, M.M. Discrepancy evaluation for educational program improvement and assessment. (Berkeley, CA: McCutchan Publishing. 1971), h. 70.
} 


\section{Kriteria Evaluasi}

Untuk memperjelas kriteria evaluasi implementasi kebijakan sosialisasi penerimaan mahasiswa baru pascasarjana IAIN Kendari dalam penelitian ini peneliti membuat kriteria seperti pada tabel.berikut ini:

\begin{tabular}{|c|c|c|c|c|}
\hline $\begin{array}{l}\mathbf{N} \\
\mathbf{0}\end{array}$ & $\begin{array}{c}\text { Tahap } \\
\text { Evaluasi }\end{array}$ & $\begin{array}{c}\text { Aspek Yang } \\
\text { Dievaluasi }\end{array}$ & $\begin{array}{c}\text { Sumber } \\
\text { Informasi }\end{array}$ & $\begin{array}{c}\text { Jenis } \\
\text { Instrumen }\end{array}$ \\
\hline 1. & $\begin{array}{l}\text { Tahap } \\
\text { Definisi } \\
\text { (definition } \\
\text { stage) atau } \\
\text { Perencanaan }\end{array}$ & $\begin{array}{l}\text { 1. Kebijakan } \\
\text { Sosialisasi } \\
\text { Penerimaan } \\
\text { Mahasiswa Baru } \\
\text { 2. Tujuan dan } \\
\text { Sasaran sosialisasi } \\
\text { Penerimaan Calon } \\
\text { Mahasiswa Baru }\end{array}$ & $\begin{array}{l}\text { - Pendap } \\
\text { at lisan : Rektor, } \\
\text { Warek I, } \\
\text { Direktur } \\
\text { Pascasarjana } \\
\text { dan Ketua } \\
\text { Program Studi } \\
-\quad \quad \quad \text { Dokum } \\
\text { en tertulis } \\
\text { tentang } \\
\text { kebijakan } \\
\text { sosialisasi } \\
\text { penerimaan } \\
\text { Mahasiswa Baru }\end{array}$ & $\begin{array}{l}\text { - Wawancara } \\
\text { - Dokumentasi }\end{array}$ \\
\hline 2 & $\begin{array}{l}\text { Tahap } \\
\text { Instalasi } \\
\text { (installation } \\
\text { stage) }\end{array}$ & $\begin{array}{l}\text { 1. Persiapan } \\
\text { pelaksanaan } \\
\text { Sosilisasi penerimaan } \\
\text { mahasiswa baru } \\
\text { terkait Sumber daya } \\
\text { yang dibutuhkan } \\
\text { 2. Persiapan } \\
\text { pelaksanaan } \\
\text { sosialisasi terkait } \\
\text { dengan administrasi } \\
\text { persuratan. }\end{array}$ & $\begin{array}{l}\text { - Kesiap } \\
\text { an sumber daya } \\
\text { terkait } \\
\text { pembiayaan, } \\
\text { bahan-bahan } \\
\text { sosialisasi dan } \\
\text { Tim Sosialiasi: } \\
\text { Keuangan, } \\
\text { program studi } \\
\text { - Kesiap } \\
\text { an administrasi } \\
\text { persuratan: } \\
\text { Kepegawaian } \\
\text { dan program } \\
\text { studi }\end{array}$ & $\begin{array}{l}\text { - Wawancara } \\
\text { - Dokumentasi }\end{array}$ \\
\hline
\end{tabular}




\begin{tabular}{|c|c|c|c|c|}
\hline 3 & $\begin{array}{l}\text { Tahap } \\
\text { Proses } \\
\text { (process } \\
\text { stage) }\end{array}$ & $\begin{array}{l}\text { 1. Proses sosialisasi } \\
\text { penerimaan calon } \\
\text { mahasiswa baru } \\
\text { terkait waktu } \\
\text { pelaksanaan } \\
\text { 2. Proses sosialisasi } \\
\text { penerimaan calon } \\
\text { mahasiswa baru } \\
\text { terkait bentuk-bentuk } \\
\text { sosialisasi } \\
\text { 3. Proses sosialisasi } \\
\text { terkait mekanisme } \\
\text { pelaksanaan } \\
\text { sosialisasi. }\end{array}$ & $\begin{array}{l}\text { Pelaksanaan } \\
\text { sosialisasi } \\
\text { terkait waktu } \\
\text { pelaksanaan, } \\
\text { bentuk } \\
\text { sosialisasi dan } \\
\text { makanisme } \\
\text { pelaksanaan } \\
\text { sosialisasi : } \\
\text { Direktur } \\
\text { Pascasarjana, } \\
\text { Ketua program } \\
\text { studi, Tim } \\
\text { Sosialisasi, } \\
\text { Mahasiswa, dan } \\
\text { Lembaga } \\
\text { keuangan } \\
\text { syariah }\end{array}$ & $\begin{array}{l}\text { - Wawancara } \\
\text { - Dokumentasi } \\
\text { - Observasi }\end{array}$ \\
\hline 4 & $\begin{array}{l}\text { Tahap } \\
\text { Produk } \\
\text { (product } \\
\text { stage) }\end{array}$ & $\begin{array}{l}\text { 1. Pencapaian } \\
\text { tujuan pelaksanaan } \\
\text { Sosilisasi penerimaan } \\
\text { calon mahasiswa baru } \\
\text { 2. Pencapaian } \\
\text { sasaran pelaksanaan } \\
\text { sosialisasi } \\
\text { penerimaan calon } \\
\text { mahasiswa baru. }\end{array}$ & $\begin{array}{l}\text { Capaian jumlah } \\
\text { dan sasaran } \\
\text { pelaksanaan } \\
\text { sosialisasi calon } \\
\text { mahasiswa baru: } \\
\text { Tim Sosialisasi, } \\
\text { Ketua program } \\
\text { studi. }\end{array}$ & $\begin{array}{l}\text { - Wawancara } \\
\text { - Observasi } \\
\text { - Dokumentasi }\end{array}$ \\
\hline 5 & $\begin{array}{l}\text { Tahap } \\
\text { Program } \\
\text { Membandin } \\
\text { gkan } \\
\text { (Programe } \\
\text { comparison } \\
\text { stage) }\end{array}$ & $\begin{array}{l}\text { Perbandingan jumlah } \\
\text { pendaftar calon } \\
\text { mahasiswa baru } \\
\text { dengan jumlah lokasi } \\
\text { tujuan dan sasaran } \\
\text { pelaksanaan } \\
\text { sosialisasi } \\
\text { penerimaan calon } \\
\text { mahasiswa baru }\end{array}$ & $\begin{array}{l}\text { Jumlah } \\
\text { pendaftar calon } \\
\text { mahasiswa baru } \\
\text { dan jumlah } \\
\text { tujuan dan } \\
\text { sasaran } \\
\text { pelaksanaan } \\
\text { sosialisasi } \\
\text { penerimaan } \\
\text { MABA: Ketua } \\
\text { program studi } \\
\text { dan Tim } \\
\text { Sosilisasi }\end{array}$ & $\begin{array}{l}\text { - Wawancara } \\
\text { - Dokumentasi }\end{array}$ \\
\hline
\end{tabular}




\section{Metode}

Penelitian ini menggunakan analisis diskriptif kualitatif. Tujuan penelitian ini untuk mengetahui bagaimana program tersebut dapat diimplementasikan, sejauhmana terlaksananya program, ketercapaian tujuan program seperti yang ditetapkan, dan untuk mengetahui kendala dalam implementasi program tersebut. ${ }^{20}$. Sedangkan metode penelitian yang digunakan adalah pendekatan penelitian kualitatif.

Model penelitian evaluasi yang digunakan yaitu Model DEM (Discrepancy Evaluation Model), model menurut Provus yang disebut juga Model Kesenjangan. Hal ini berdasarkan bahwa dalam pelaksanaan sosialisasi penerimaan mahasiswa baru pascasarjana perlu dilihat kesenjangan-kesenjangan yang terjadi antara hasil yang diharapkan dengan yang terjadi di lapangan sebagai tolak ukur keberhasilan pelaksanaan rekrutmen.

Pendekatan ini memperkenalkan pelaksanaan evaluasi dengan langkah-langkah yang perlu dilakukan menurut Provus, meliputi: Tahap Definisi (definition stage), Tahap Instalasi (installation stage), Tahap Proses (process stage), Tahap Produk (product stage, Tahap Membandingkan (comparison stage).

\section{Hasil Penelitian dan Pembahasan}

Hasil evaluasi implementasi kebijakan sosialisasi penerimaan mahasiswa baru program studi ekonomi syariah pascasarjana IAIN Kendari berdasarkan hasil wawancara, dokumentasi dan observasi dimana kebijakan yang digariskan dalam pedoman akademik IAIN Kendari.

Kebijakan sosialisasi penerimaan mahasiswa baru pascasarjana IAIN Kendari telah dilaksanakan sejak pembukaan program pascasarjana tahun 2014. Hasil evaluasi kebijakan sosialisasi penerimaan mahasiswa baru pascasarjana khususnya dapat dijelaskan sebagai berikut:

\section{Tahap Definisi (definition stage)}

Tujuan dan sasaran kebijakan sosialisasi penerimaan mahasiswa baru pascasarjana IAIN Kendari untuk menghasilkan

${ }^{20}$ Suharsimi Arikunto dan Cepi Safruddin, Evaluasi Program pendidikan: Pedoman Teoritis Praktis Bagi Mahasiswa dan Praktisi Pendidikan cetakan ketiga (Jakarta: Bumi Aksara, 2009),h.7 
mahasiswa baru yang bermutu diukur dari pemenuhan kriteria seleksi, jumlah peminat, proporsi pendaftar terhadap daya tampung, dan proporsi yang diterima terhadap yang registrasi sebagimana yang digariskan dalam pedoman akademik pascasarjana IAIN Kendari dengan fakta dilapangan belum sepenuhnya terlaksana. Hal ini disebabkan karena jumlah peminat dan pendaftar khususnya program studi ekonomi syariah masih sangat terbatas.

Berdasarkan penelusuran dokumen, wawancara dan observasi dapat dijelaskan bahwa kebijakan sosialisasi dan penerimaan mahasiswa baru telah ditetapkan dalam pedoman akademik IAIN Kendari. Proses perumusan kebijakan rekrutmen calon mahasiswa baru meliputi; penetapan kriteria seleksi mahasiswa baru, sistem pengambilan keputusan, dan prosedur penerimaan mahasiswa baru termasuk penetapan sumber daya yang dibutuhkan telah dilaksanakan sesuai pedoman akademik IAIN Kendari.

\section{Tahap Instalasi (Instalation Stage)}

Penentuan besaran biaya perkuliahan dan biaya lain yang harus ditanggung oleh mahasiswa merupakan kewenangan Direktur Pascasarjana atas persetujuan Rektor Institut Agama Islam Negeri (IAIN) Kendari. Dalam proses pengambilan kebijakan mengenai besaran biaya perkuliahan Pascasarjana IAIN Kendari sebagai institusi pemerintah (negeri) tetap mengacu pada ketentuan yang diatur oleh pemerintah yaitu standar biaya umum (SBU) pada setiap tahun berjalan dengan memperhatikan besaran kebutuhan operasional Pascasarjana IAIN Kendari yang dituangkan dalam RKAKL Pascasarjana IAIN Kendari setiap tahunnya.

Terkait waktu pendaftaran dan ujian masuk ditentukan secara bersama antara pengola Pascasarjana dengan unsur pimpinan yang terkait dalam lingkup IAIN Kendari. Penerimaan mahasiswa baru Pascasarjana IAIN Kendari dilaksanakan setiap tahun yaitu pada bulan Maret - Agustus.

Pada aspek promosi dalam penerimaan calon mahasiswa baru Pascasarjana IAIN Kendari merupakan salah satu bagian dari rencana kerja tahunan yang dirumuskan secara bersama-sama oleh seluruh pengola Pascasarjana bersama unsur pimpinan IAIN Kendari. Kegiatan promosi dalam rangka rekrutmen calon mahasiswa Pascasarjana merupakan salah satu hal penting dilakukan untuk memperluas pengetahuan masyarakat tentang keberadaan Pascasarjana 
IAIN Kendari. Lebih lagi mengingat keberadaan lembaga ini tergolong baru sehingga kegiatan promosi dipandang urgen dilakukan. Pada sisi persiapan administrasi dilaksanakan dengan menyiapkan Surat Tugas dan SPPD, surat menyurat ke daerah atau lokasi tempat pelaksanaan sosialisasi, spanduk, dan bahan sosialisasi lainnya.

Pada tahapan ini pengelola pascasarjana mengusulkan penerbitan surat tugas dan SPPD kepada tim sosialisasi, selanjutnya tim sosialisasi mengirimkan surat permintaan untuk melakukan sosialisasi pada kabupaten/kota, kantor dan sekolah yang menjadi sasaran sosialisasi.

\section{Tahap Proses}

Kewenangan melaksanakan sosialisasi penerimaan mahasiswa baru pascasarjana diserahkan sepenuhnya kepada unit pascasarjana IAIN Kendari. Pengelola pascasarjana selanjutnya melakukan rapat internal untuk menetapkan berbagai bentuk persiapan untuk melakukan sosialisasi. Bentuk persiapan tersebut seperti pembentukan tim sosialisasi, tujuan dan sasaran sosialisasi, menyiapkan bahan dan materi sosialisasi, metetapkan waktu sosialisasi dan bentuk dan mekanisme sosialisasi.

Banyak cara yang dilakukan dalam menjaring calon mahasiswa baru Pascasarjana IAIN Kendari, antara lain; melalui media cetak seperti memasang iklan di harian Kendari Post yang merupakan media cetak terbesar di Sulawesi Tenggara. Press rilis yang kemudian dimuat dalam bentuk berita juga pihak pengelola Pascasarjana dalam rangka promosi dan sosialisasi Pascasarjana IAIN Kendari.

Cara lain yang ditempuh pihak pengelola Pascasarjana yaitu memasang spanduk di tempat-tempat yang strategis, penyebaran brosur, dan sosialisasi ke sejumlah institusi sekolah/madrasah dan instansi pemerintah maupun swasta.

Waktu pelaksanaan sosialisasi penerimaan mahasiswa baru pascasarjana ditetapkan melalui rapat internal pengelola pascasarjana yang disesuaikan dengan waktu yang ditetapkan oleh kantor dan sekolah yang telah menerima surat permohonan untuk melakukan sosialisasi yang dikirim oleh tim sosialisasi dari pascasarjana. Sejak lima tahun pelaksanaan sosialisasi dimulai pada bulan April sampai dengan Agustus setelah program studi S1 selesai melaksanakan sosialisasi dan seleksi penerimaan mahasiswa baru. 
Berdasarkan data dan fakta dilapangan baik dari dokumentasi, wawancara dan obesrvasi pada tahapan proses sosialisasi dengan kebijakan yang telah digarisnkan pada pedoman akademik pascasarjana IAIN Kendari menunjukkan bahwa belum semua dapat dilaksanakan dengan baik. Hal ini disebabkan beberapa kendala, seperti lambatnya penerbitan surat tugas dan SPPD bagi Tim sosialisasi. Dana sosialisasi yang tidak dicaikan sebalum pelekasanaan sosialisasi sehingga berdampak pada persiapan bahan dan materi sosialisasi. Waktu pelaksanaan sosialisasi yang terlalu sempit dimana kesibukan kantor dan sekolah sebagai sasaran sosialisasi bersamaan dengan waktu sosialisasi.

\section{Tahap Produk (Product Stage)}

Sebagai akibat dari beberapa masalah yang dijelaskan pada tahapan proses sosialisasi diatas jumlah pendaftar mahasiswa baru pascasarjana IAIN Kendari tidak signifikan. Selain masalah yang telah dikemukakan juga dipengaruhi oleh beberapa faktor seperti hal-hal berikut:

a) Sulitnya mendapat Ijin belajar bagi PNS yang bekerja dilingkup kementerian agama khususnya.

b) Pelaku bisnis syariah dan perbankan syariah tidak memiliki program untuk memberikan kesempatan kepada karyawan melanjutkan studi S2, karena pengembangan karir, kompetensi dan kinerja karyawan dilakukan melalui training yang dilakukan oleh kantor pusat secara berkala.

c) Sasaran sosialisasi belum menyentuh disebabkan oleh pendanaan, bentuk, mekanisme dan waktu yang dibutuhkan untuk melaksanakan sosialisasi.

d) Akreditasi program studi yang masih rendah sehingga bagi PNS yang mau melanjutkan studi belum berminat ke pascasarjana IAIN Kendari.

\section{Kesimpulan dan Implikasi}

Kebijakan sosialisasi penerimaan mahasiswa baru pascasarjana IAIN Kendari khususnya program studi ekonomi syariah telah tercantum pada pedoman akademik IAIN Kendari. Berdasarkan penelusuran dokumen, wawancara dan observasi dapat dijelaskan bahwa Sistem rekrutmen mahasiswa baru mencakup: kebijakan rekrutmen calon mahasiswa baru, kriteria seleksi mahasiswa baru, 
sistem pengambilan keputusan, dan prosedur penerimaan mahasiswa baru telah dilaksanakan sesuai yang telah ditetapkan pada pedoman akademik pascasarjana IAIN Kendari.

Sosialisasi penerimaan calon mahasiswa baru Pascasarjana IAIN Kendari merupakan salah satu bagian dari rencana kerja tahunan yang dirumuskan secara bersama-sama oleh seluruh pengola Pascasarjana bersama unsur pimpinan IAIN Kendari. Kegiatan promosi dalam rangka rekrutmen calon mahasiswa Pascasarjana merupakan salah satu hal penting dilakukan untuk memperluas pengetahuan masyarakat tentang keberadaan Pascasarjana IAIN Kendari. Lebih lagi mengingat keberadaan lembaga ini tergolong baru sehingga kegiatan promosi dipandang urgen dilakukan.

Kewenangan melaksanakan sosialisasi penerimaan mahasiswa baru pascasarjana diserahkan sepenuhnya kepada unit pascasarjana IAIN Kendari. Pengelola pascasarjana selanjutnya melakukan rapat internal untuk menetapkan berbagai bentuk persiapan untuk melakukan sosialisasi. Bentuk persiapan tersebut seperti pembentukan tim sosialisasi, tujuan dan sasaran sosialisasi, menyiapkan bahan dan materi sosialisasi, metetapkan waktu sosialisasi dan bentuk dan mekanisme sosialisasi.

Sebagai akibat dari beberapa masalah yang dijelaskan pada tahapan proses sosialisasi diatas jumlah pendaftar mahasiswa baru pascasarjana IAIN Kendari tidak signifikan. Selain masalah yang telah dikemukakan juga dipengaruhi oleh beberapa faktor seperti hal-hal berikut:

a) Sulitnya mendapat Ijin belajar bagi PNS yang bekerja dilingkup kementerian agama khususnya.

b) Pelaku bisnis syariah dan perbankan syariah tidak memiliki program untuk memberikan kesempatan kepada karyawan melanjutkan studi S2, karena pengembangan karir, kompetensi dan kinerja karyawan dilakukan melalui training yang dilakukan oleh kantor pusat secara berkala.

c) Sasaran sosialisasi belum menyentuh disebabkan oleh pendanaan, bentuk, mekanisme dan waktu yang dibutuhkan untuk melaksanakan sosialisasi

d) Akreditasi program studi yang masih rendah sehingga bagi PNS yang mau melanjutkan studi belum berminat ke pascasarjana IAIN Kendari. 
Hasil evaluasi tahap membandingkan implementasi kebijakan sosialisasi penerimaan mahasiswa baru pascasarjana IAIN Kendari khususnya ekonomi syariah dengan katagori "belum dilaksanakan dengan maksimal". Sebagai akibat tidak maksimalnya pelaksanaan sosialisasi maka jumlah pendaftar calon mahasiswa baru tidak signifikan.

Rekomendasi untuk perbaikan dan penyempurnaan pelaksanaan kebijakan sosialisasi penerimaan mahasiswa baru ekonomi syariah pascasarjana IAIN Kendari sebagai berikut :

1. Perlu segera ditindaklanjuti hasil visitasi akreditasi program studi ekonomi syariah untuk memberikan kepercayaan kepada masyarakat melanjutkan studi S2 di IAIN Kendari

2. Perlu mengembangkan bentuk-bentuk kerjasama dengan instansi terkait terutama yang berkaitan dengan Izin belajar bagi PNS yang berada dilingkup Kementerian Agama Provinsi Sulawesi Tenggara, Pemda dan dunia usaha.

3. Meningkatkan jumlah dan kompetensi Dosen dan tenaga pengelola pascasarjana agar dapat melakukan sosialisasi dengan efektif kepada lembaga terkait.

4. Perlu penyiapan dana yang cukup untuk melakukan promosi dan sosialisasi baik melalui media cetak, elekronik, kunjungan ke kantor-kantor dan sekolah serta melalui media informasi online.

5. Mendorong berbagai usaha untuk melakukan sosialisasi dengan mempercepat penerbitan surat tugas dan SPPD termasuk pencairan dana sosialisasi sebelum pelaksnaan sosialisasi

6. Meningkatakan komitmen pengelola pascasarjana untuk senantiasa mensosialisasikan program studi yang ada dipascasarjana IAIN Kendari. 


\section{Daftar Pustaka}

Carol H. (1972). Weiss, Evaluation Research : Methods for Assessing Program Effectiveness, New Jersey: Prentice Hall.

Dunn, N. William. (2003). Analisis Kebijakan Publik. Yogyakarta :Gajah Mada University Press.

Eriza, F. (2006). Implementasi Proyek Pengelolaan Sumber Dya Pesisir dan Laut Marine Coastal Resources Management Project : Medan: Program pascasarjana USU.

Gamage, David Thenuwara, and Nicholas Sun Keuang Pang. (2003). Leadership and Management Education. Hongkong: The Chinese University Press.

Goggin, Malcom L, et all. (1990). Implementation, Theory and Practice, USA : Toward a Third Generation, Scott, Foresmann Company.

Gustina Ida. (2008). Implementasi Program Penanggulangan Kemiskinan di Perkotaan (P2KP) di Kecamatan Medan Maimun,Medan: Program pascasarjana USU.

Harahap J.S. (2004). Implementasi Proyek Jembatan :Medan: Program pascasarjana USU.

Heinz Weihrich and Harold Koontz. (1993). Management A Global Perspective Tent Edition, New York: McGraw-Hill, Inc.

J.W. Creswell. (2003). Research Design: Qualitative, Quantitative, and Mixed Methods Approaches. London: Sage Publication.

Lexy J. Moleong. (2006). Metodologi Penelitian Kualitatif, Edisi Revisi, Bandung : Penerbit: Remaja Rosdakarya.

Malcolm Provus. (1998). The Disprepancy Evaluation Model: A Systematic Approach for the Management Specialization Program: A Formative Evaluation (Journal of Contruction Education, 3(2), Summer .64-70

Michael Hill \& Peter Hope. (2002). Implementing Public Policy ; Governance in Theory and Practice, London: Sage Publication.

Miles, M.B. dan Huberman, A.M. (2007). Analisis Data Kualitatif: Buku Sumber Tentang Metode Baru Jakarta: UI Press.

Noeng H. Muhajir. (2003). Metodologi Penelitian Kebijakan dan Evaluation Research, Yogyakarta: Rake Sarakin.

Nugroho Riant. (2009). Public Policy. Jakarta : PT Elex Media Komputindo Kelompok Gramedia. 
Sudijono. (2011). Pengantar Evaluasi Pendidikan ; Jakarta ; Raja Grafindo Persada.

Suharsimi Arikunto dan Cepi Safrudin. (2004). Evaluasi Program Pendidikan: Pedoman Teoritis Praktis Bagi Mahasiswa dan Praktisi Pendidikan (Jakarta: Bumi Aksara, 2004).

Syafarudin. (2008). Efektifitas Kebijakan Pendidikan. Jakarta: Rineka Cipta.

Tilaar H.A.R \& Riant Nugroho. (2008). Kebijakan Pendidikan: Pengantar untuk Memahami Kebijakan Pendidikan dan Kebijakan Pendidikan sebagai Kebijakan Publik. Jakarta: Pustaka Pelajar.

Weimer David L and Aiden R. Vining. (1992). Policy Analysis : Concepts and Practice. Englewood Cliffs. New Jersey, Prentice Hall, Inc.

Winarno Budi. (2008). Kebijakan Publik: Teori dan Prose, Yogyakarta: Media Pressindo.

Worten B. Blaini. Sanders, R. James, Fitzpatrick, L. Jodi. (1997). Program Evaluasi Alternatif Approach and Pratical Guidelines (New York: Wesley Longman). 